\title{
High Incidence of Shell Injuries in an Isolated Population of the Spur-thighed Tortoise (Testudo graeca ibera) from Romania
}

\author{
Valentina E. MORARU ${ }^{1}$, Stefan R. ZAMFIRESCU ${ }^{2}$, \\ Marius A. CIOCĂNÂU ${ }^{3}$, Dumitru MURARIU ${ }^{4}$
}

\begin{abstract}
${ }^{1}$ Faculty of Biology, University of Bucharest, 91-95 Splaiul Independenței Blvd., 050095 Bucharest, Romania.

${ }^{2}$ Faculty of Biology, "Alexandru Ioan Cuza” University, 20 A Carol I Blvd., 700505 Iași, Romania. ${ }^{3}$ Faculty of Veterinary Medicine, University of Agronomic Sciences and Veterinary Medicine, 105 Independenței Str., 050097 Bucharest, Romania.

${ }^{4}$ Institute of Biology - Bucharest, Romanian Academy, 296 Splaiul Independenței, 060031 Bucharest, Romania

*corresponding author, e-mail: moraru.valentina@yahoo.com
\end{abstract}

Received: January 14, 2018; Accepted: May 10, 2018; Available online: June 27, 2018; Printed: June 30, 2018

\begin{abstract}
Testudo graeca is one of the two species of tortoises from Romania, the other one being Testudo hermanni. It is well known that this species has a broad but fragmented distribution range and this fact labels this species as Vulnerable in the IUCN Red List. The population of Testudo graeca ibera from the Natura 2000 site "Marine dunes from Agigea" is characterized by a high percentage of injuries (84\%) from the total of 43 individuals found alive. A high percentage of individuals have injuries on all the plates from carapace and plastron. All lesions appear to be chronic, suggesting that there is a series of predisposing factors, such as: inadequate terrain (concrete, metal, broken glass and other hard objects), high-density dog population and coprophagia, which could be a sign of unbalanced nutrition. This is the first report of a population of Testudo graeca which has such a high percentage of individuals with shell damage.
\end{abstract}

Key words: lesions, Agigea, Dobroudja, natural protected area.

\section{INTRODUCTION}

Diseases are significant factors that lead to species decline worldwide (Smith at al., 2009). Some reptile populations are already experiencing catastrophic declines due to disease-induced mortality (Jacobson, 1993). In chelonians, diseases have been frequently reported due to trauma (burns or fractures), malnutrition (calcium-related failure, vitamin D3 or environmental lighting), metabolic/genetic factors and a variety of bacteria or fungal infections (Keymer, 1978a, b; Frye, 1991; Homer et al., 1998; Lafortune et al., 2005; Barten, 2006; Mader, 2006a, b; Adkesson et al., 2007). Injuries on the tortoise's carapace and plastron are often observed in the wild, but most of the cases are relatively mild (Buică et al., 2014). Skin and shell infections are caused by either bacteria or fungi (Mader, 2006a) and all the disturbances occurring in the life of a tortoise are inscribed as a message on its shell (Lynn \& Ullrich, 1950).

The spur-thighed tortoise (Testudo graeca Linnaeus, 1758) has a broad but fragmented distribution range, comprising regions from southern Europe, North Africa and the Middle East. Many of species' populations are isolated, some of them being apart from one another at a distance of tens of kilometers. The species is protected by the European (European Directive 92/43/EEC) and Romanian legislation (Law 13 of 1993, Government Emergency Ordinance no. 57/2007). At the same time, at a global 
level, it is listed as Vulnerable (VU) in the IUCN Red List (Tortoise \& Freshwater Turtle Specialist Group, 1996), while in Romania it is considered endangered, due to its restricted range (found only in south-eastern Romania), habitat destruction, poaching and deliberate persecution (Iftime, 2005).

In this paper, we present a case study on an isolated population of spur-thighed tortoise from Romania, with a remarkably high incidence of shell damage, and explore the possible causes for the injuries as well as implications for conservation.

\section{MATERIALS AND METHODS}

The Natura 2000 site "Marine dunes from Agigea" (ROSCI0073) is located in the central-eastern extremity of Constanța County, Romania, at about 200 meters from the Black Sea shore (Fig. 1). It is the only habitat of marine dunes located outside the Danube Delta Biosphere Reserve, preserved in the Romanian Black Sea coast. The climate is temperate continental with an average annual temperature of $11.2^{\circ} \mathrm{C}$ and $300-400 \mathrm{~mm}$ annual rainfall. In this area, sandy soils predominate and the vegetation installed is characteristic of the xerophyte and xeromesophyte vegetation communities (Fig. 2A-B). A small part of this protected area is covered by concrete bunkers from World War II (Fig. 2C-D) and the entire area is surrounded by a concrete fence with very few opportunities for entry and exit of animals (Fig. 2E-F). Tortoises have occurred naturally in the area, at least since the 1960's (Andriescu, I., pers. com.), but we describe the current population as "isolated" as many individuals were introduced

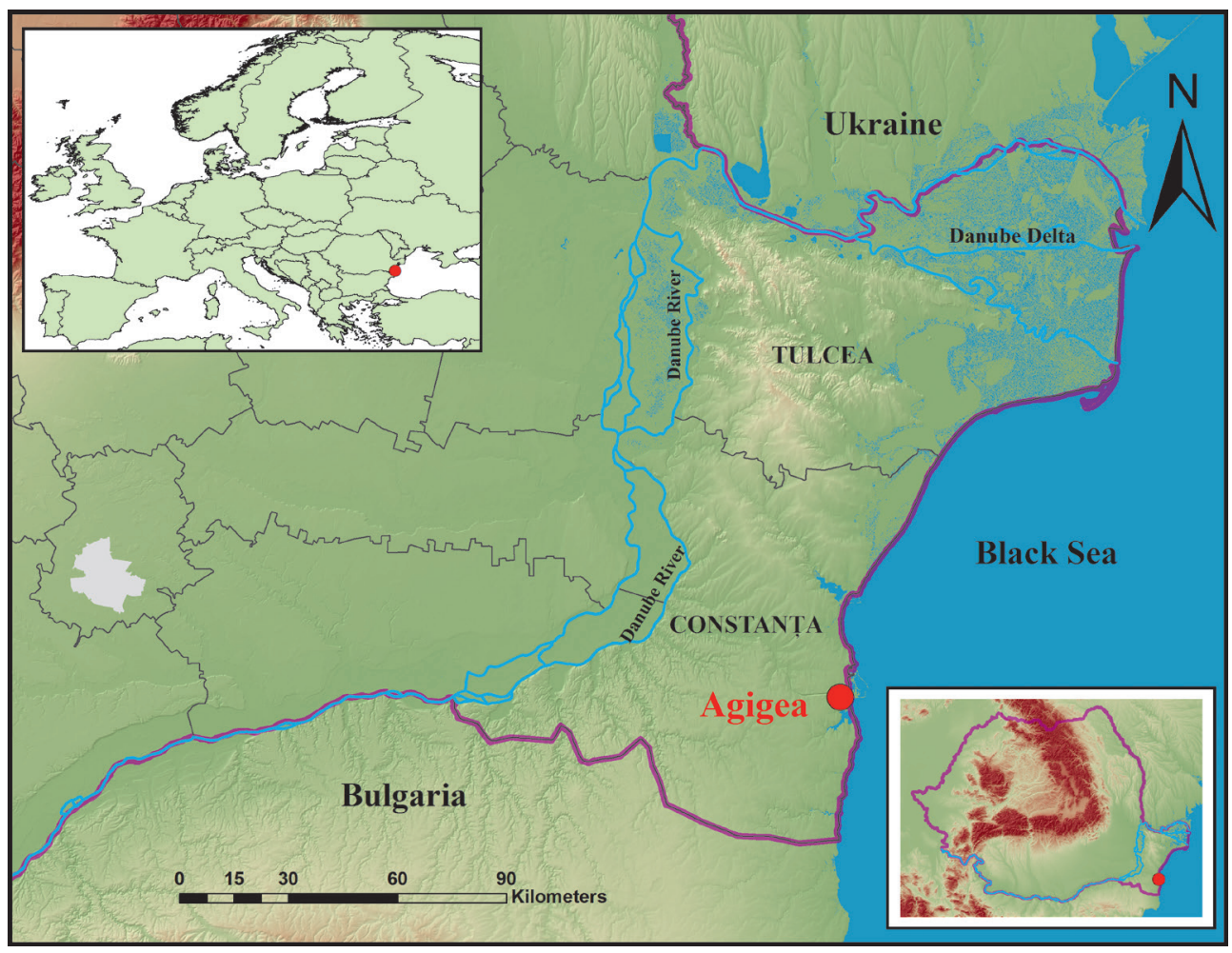

Fig. 1 - Location of the study area in Romania. 

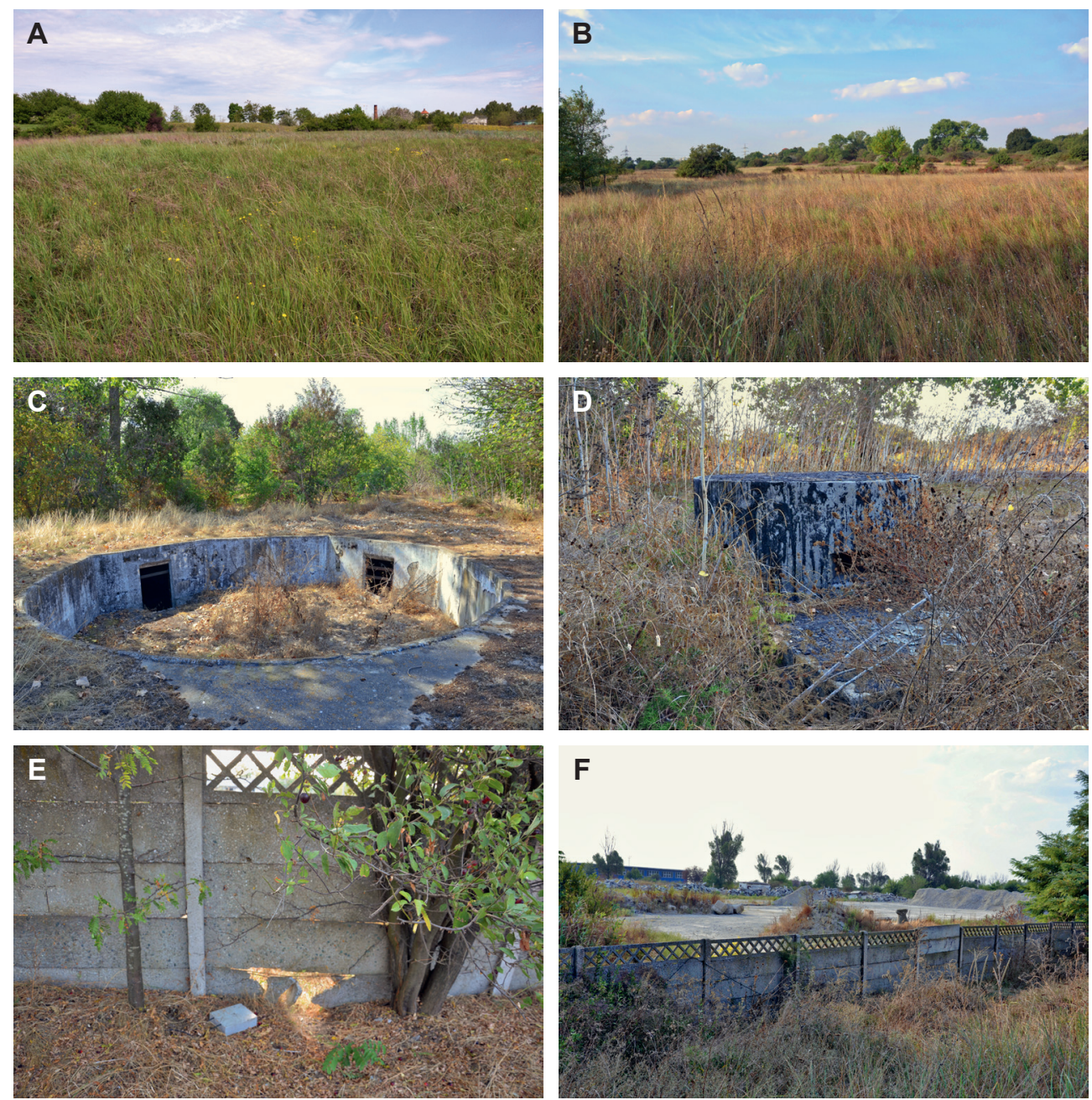

Fig. 2 - General aspects of the investigated habitat: (A-B) vegetation from the site, $(\mathrm{C}-\mathrm{D})$ bunkers from World War II, (E-F) concrete fence from the protected area. Photos by VEM.

in the reserve from the entire continental Dobrogea, and because the connectivity to other populations is surely impeded by the concrete fence.

This study was conducted in May 2015 and September 2016, tortoises were actively searched (by one person every day) using diurnal transects in time interval 8 A.M. - 19 P.M. For each captured individual, we determined age class, sex, straight carapace length (SCL) and body weight (BW). The individuals were sexed based on external morphological characters (Carretero et al., 2005) and we used a threshold of $100 \mathrm{~mm}$ in SCL to separate juveniles and subadults from adults (Strubbs et al., 1984). The individuals were photographed and data were collected on the spot. After these procedures, the animals were released in the same place where they had been captured. 
Diagrams were performed using the programs Past 3.01 (Fig. 4) and Microsoft Excel (Fig.5) and the map was made using ArcGIS Desktop 9.3 (Fig.1).

\section{RESULTS AND DISCUSSION}

During the study, we found 46 tortoises, of which three were dead. We did not recapture specimens previously encountered. Of the live tortoises, 38 presented injuries on carapace and plastron and the rest of five were healthy. Thus, a high percentage $(84 \%)$ of the sample presented external injuries. Apart from the three dead tortoises, the remaining 38 displayed no signs of human-inflicted injuries (Fig. 3 ). Regarding the age structure of population, we found 41 adults ( 25 males and 16 females) and two subadult individuals. The differences between males and females, from SCL and BW point of view, are shown in Fig. 4.

The highest percentages of natural and human-caused injuries $(35.78 \%$ of a sample of 109 individuals and 35\% of a sample of 580 individuals) in populations of Testudo graeca from Romania were reported in Dumbrăveni Forest Natural Reserve and Măcin Mountains National Park (Buică et al., 2014). Comparing with our data, all individuals from Agigea displayed only natural injuries. We observed that a significant percentage of individuals has all the plates affected by injuries (for example individuals from Fig. 3), as can be seen 11 individuals (31\% from the total) had between 35-37 affected carapace plates (Fig. 5A). While on the plastron the number of affected plates was significant, as can be seen 11 individuals ( $31 \%$ of the total) had between 9-12 affected plastron plates (Fig. 5B). On both sides of the shell, males have the largest number of affected scutes, 8 individuals with 35-37 affected carapace plates (Fig. 5A) and 9 individuals with 9-12 affected plastron plates (Fig. 5B). Males have a higher rate of injuries on both the carapace and plastron (Fig. 5) probably due to battles between males or their higher mobility during reproduction periods.

We observed unequal adult sex ratio (1.56:1 - male to female, which differ from the expected 1:1) and the presence of the subadult individuals is very low (just two subadult individuals from the total of 43) and this fact is probably caused by the small size, camouflage colors, dense vegetation and less active behavior (Buică, 2011).

The pathology encountered had several common patterns: traumatic lesions either on the lower or upper shell or both, the protective keratin layer is discontinued and an overlapping bacterial invasion starts to multiply. All lesions appear to be chronic, suggesting that there is a series of predisposing factors, such as inadequate terrain (concrete, metal, broken glass and other hard objects) and high-density dog population. Various species of chelonians, especially the herbivores, have been observed (both in the wild and in captivity) to consume dog feces (McArthur et al., 2004) and we have also noticed this to T. graeca ibera from Agigea. This behavior facilitates the transmission of pathogenic bacteria, protozoa, viruses and parasites (McArthur et al., 2004).

Pathologies can be described by identifying key features on different parts of anatomical segments of the shell. Physical pattern evidence includes primary lesions like abrasions, puncture wounds and lacerations followed by infection. The observed lesions have a tendency to chronicization (comparing recent lesions with old lesions). The interacting and overlapping behavioral and ecological factors could offer an explanation for the localization of the lesions. Most plastron lesions consist of abrasions, which might be closely associated with the nature of the environment: concrete, metal and other hard objects (Fig. 3C). While most carapace findings (puncture wounds, lacerations, abrasions, ulceration) imply that they probably represent canine 

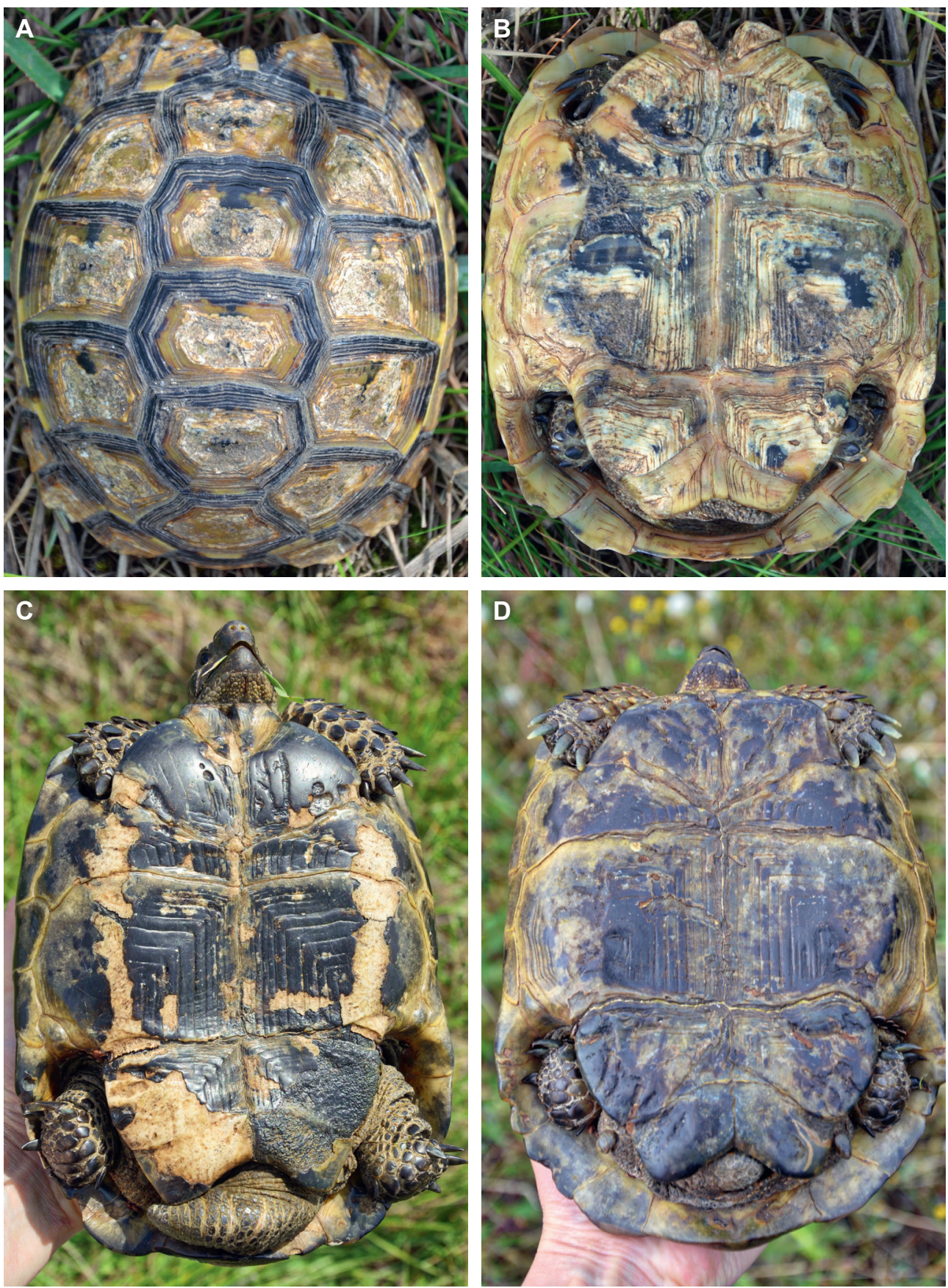

Fig. 3 - Some examples of individuals of Testudo graeca ibera with shell diseases: (A-B) individual with all affected plates - May 2015, (C) male with plastron lesions due to abrasions - May 2015, (D) male with canine bite (femoral and anal plates) - May 2015. Photos by VEM. 


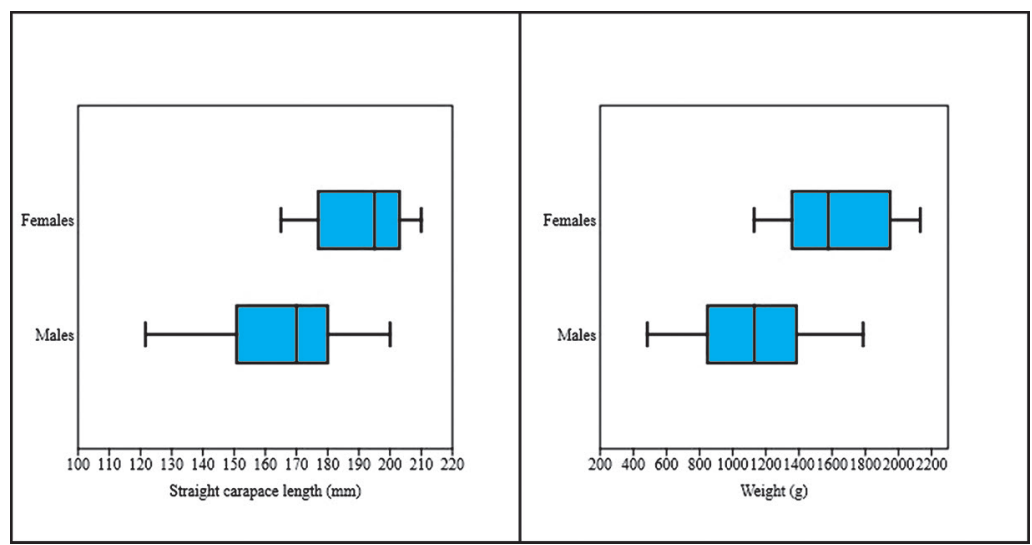

Fig. 4 - Size (left) and body mass (right) structure of the Testudo graeca population.

bite marks (several feral dogs were observed in the nature reserve) (Fig. 3D). Both elements showing bite-mark-like deformities usually involves the edges of the shell while abrasions are associated with the prolonged inappropriate surface contact. Several important functions of the shell are altered by traumatic injuries, for example protection from predators, camouflage, shelter for aestivation or hibernation, heat storage, fat storage, calcium storage, protection the body against sudden temperature changes (Cebra-Thomas et al., 2005).

Although a large variety of bacteria can live on tortoise shell, those that are mainly associated with keratin degradation can also reasonably be linked with shell degradation because the scutes that comprise the outer shell layer are composed of keratin (Valerie et al., 2008). Tortoise's shell (the bottom side) are occasional in close contact with warm and damp soil (Auffenberg, 1969) and once the keratin layer discontinued, bacteria gain access to ideal growing conditions (Ultsch \& Anderson, 1986; Valerie et al., 2008).

It is the first time when a population of Testudo graeca presents such a highest number of individuals with shell damage. The presence of these injuries in such a high density should be a warning for the authority in charge with the conservation of the studied site.

We consider conservation measures: (1) stopping dogs from accessing the protected natural area; (2) elimination of the metal, broken glass and all the hard

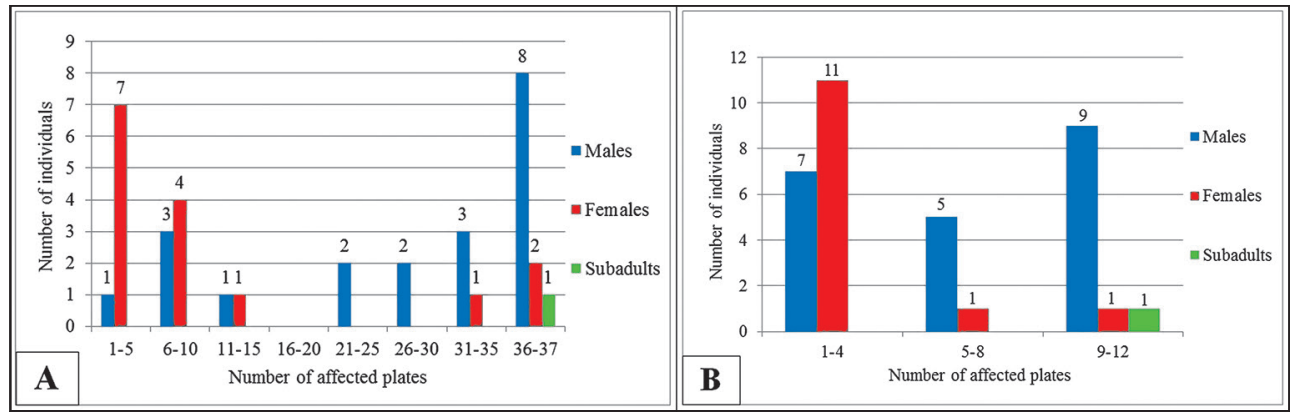

Fig. 5 - Number of affected plates from carapace (A) and plastron (B). 
objects and (where it is applicable) covering concret surface with soil; (3) stopping uncontrolled releases of individuals of Testudo graeca ibera in nature, including "Marine dunes from Agigea"; (4) performing microbiological analysis to establish the role of bacteria and fungi in the pathogenesis of the observed lesions; (5) performing genetic analysis to establish if inbreeding have an important role in lower population resistance to pathogens.

\section{ACKNOWLEDGEMENTS}

This study was supported by IDEA WILD Project, members of Moldavica Herpetological Group and the team of researchers from Marine Biological Station "Prof. Dr. Ioan Borcea" Agigea, "Alexandru Ioan Cuza" University. We thank Iulian Gherghel, Prof. Dr. Maria Pătroescu, IT Eng. Diana Boboc and reviewers who offered useful critical comments that significantly improved this paper.

\section{REFERENCES}

ADKESSON, M. J., K. E. TRAVIS, M. A. WEBER, J. P. KIRBY, R. E. (2007) Vacuum-assisted closure for treatment of a deep shell abscess and osteomyelitis in a tortoise. Journal of the American Veterinary Medical Association, 231: 1249-1254.

AUFFENBERG, W. (1969) Tortoise behavior and survival. Rand McNally and Co., Chicago, USA. 38 pp.

BARTEN, S. L. (2006) Shell damage. In: Reptile medicine and surgery, 2nd edition, D. R. Mader (Ed.). Elsevier, St. Louis, Missouri, pp. 893-899.

BUICĂ, G. (2011) Preliminary data on the isolated Testudo graeca population from the "Cetatea Histria" Museum Complex, the Danube Delta Biosphere Reserve (Romania). Travaux du Muséum d'Histoire Naturelle "Grigore Antipa", vol. LIV (2): 523-528.

BUICĂ, G., R. I. BĂNCILĂ, M. TUDOR, R. PLĂIAȘU, D. COGĂLNICEANU (2014) The injuries on tortoise shells as a depository of past human impact. Italian Journal of Zoology, 81 (2): 287-297.

CARRETERO, M. A., M. ZNARI, D. J. HARRIS, J. C. MACÉ (2005) Morphological divergence among populations of Testudo graeca from west-central Morocco. Animal Biology, 55: 259-279.

CEBRA-THOMAS, J., F. TAN, S. SISTLA, E. ESTES, G. BENDER, C. KIM, P. RICCIO, C. GILBERT (2005) How the turtle forms its shell: A paracrine hypothesis of carapace formation. Journal of experimental zoology (Mol Dev Evol), 304B: 558-569.

FRYE, F. L. (1991) Biomedical and surgical aspects of captive reptile husbandry. 2nd edition. Krieger Publishing Co., Malabar, Florida.

HOMER, B. L., K. H. BERRY, M. B. BROWN, G. ELLIS, E. R. JACOBSON (1998) Pathology of diseases in wild desert tortoises from California. Journal of Wildlife Diseases 34: 508-523.

IFTIME, A. (2005) Reptilia. In: Botnariuc, N, V. Tatole (Eds): Cartea Roşie a Vertebratelor din România. Ed. Academiei Române, Bucureşti, pp.173-214. (in Romanian)

JACOBSON, E. R. (1993) Implications of infectious diseases for captive propagation and introduction program of threatened/endangered reptiles. Journal of Zoo and Wildlife Medicine, 24: 245-255.

KEYMER, I. F. (1978a) Diseases of chelonians: (1) Necropsy survey of tortoises. Veterinary Record, 103: 548-552.

KEYMER, I. F. (1978b) Diseases of chelonians: (2) Necropsy survey of tortoises. Veterinary Record, 103: $577-582$.

LAFORTUNE, M., J. F. X. WELLEHAN, D. J. HEARD, D. E. ROONEY, C. V. FIORELLO, E. R. JACOBSON, (2005) Vacuum assisted closure (Turtle VAC) in the management of traumatic shell defects in chelonians. Journal Herpetological Medicine and Surgery, 15: 4-8.

LYNN, W. G., M. C. ULLRICH (1950) Experimental production of shell abnormalities in turtles. Copeia pp. 253-262.

MADER, D. R. (2006a) Reptile Medicine and Surgery (second edition), Elsevier Saunders, $1264 \mathrm{p}$

MADER, D. R. (2006b) Metabolic bone diseases. In: Reptile medicine and surgery, D. R. MADER (Ed.). Elsevier, St. Louis, Missouri, pp. 841-851.

McARTHUR, S., R. WILKINSON, J. MEYER, C. INNIS, S. J. HERNANDEZ-DIVERS (2004) Medicine and Surgery of Tortoises and Turtles. Oxford, London: Blackwell Publishing Ltd.

SMITH, K. F., K. ACEVEDO-WHITEHOUSE, A. B. PEDERSEN (2009) The role of infectious diseases in biological conservation. Animal Conservation, 12: 1-12.

STUBBS, D., A. HAILEY, E. PULFORD, W. TYLER (1984) Population ecology of European Tortoises: review of field techniques, Amphibia-Reptilia, 5: 57-68. 
TORTOISE \& FRESHWATER TURTLE SPECIALIST GROUP (1996) Testudo graeca. The IUCN Red List of Threatened Species 1996: e.T21646A9305693. http://dx.doi.org/10.2305/IUCN. UK.1996.RLTS.T21646A9305693.en. Downloaded on 18 June 2017.

ULTSCH, G. R., J. F. ANDERSON (1986) The respiratory microenvironment within the burrows of gopher tortoises (Gopherus polyphemus). Copeia. 3: 787-793.

VALERIE, M. J., G. CRAIG, S. D. MATTHEW, R. R. SHARON (2008) Abundance, identification, and prospective participation of bacteria on Gopher tortoise shell degrandation. Journal of the Alabama Academy of Science 79 (3-4): 190-199.

*** Law 13 of 1993 that Romania ratify the Berne Convention.

*** European Directive 92/43/EEC

*** Government Emergency Ordinance no. 57/2007 on the regime of protected natural areas, the preservation of natural habitats, wild flora and fauna, approved with amendments and additions. 